\title{
Basic and Clinical Pharmaco-Therapeutics of SGLT2 Inhibitors: A Contemporary Update
}

\author{
Sanjay Kalra · Kimi K. Shetty • Vertivel B. Nagarajan · Jignesh K. Ved
}

Received: December 1, 2019 / Published online: March 4, 2020

(C) The Author(s) 2020

\begin{abstract}
Clinical relevance of sodium/glucose cotransporter 2 (SGLT2) inhibitors has been rapidly evolving across several therapy areas, apart from type 2 diabetes mellitus. While some of these developments are based on recognized scientific explanations, unexpected study findings have also shaped much of our present understanding. As the role of these agents evolves in various facets of cardiology, nephrology, hepatology and endocrinology, their optimum clinical value propositions should be realized in line with the principles of personalized medicine. An updated pharmaco-ergonomic qualification tool, based on the present evidence with these agents, would be a step in this direction. This review describes the present evidence on diverse pharmacological and therapeutic aspects for various SGLT2 inhibitors, as an attempt to provide useful guidance for optimum application in clinical practice.
\end{abstract}

Enhanced Digital Features To view enhanced digital features for this article go to https://doi.org/10.6084/ m9.figshare.11830197.

\section{S. Kalra $(\bowtie)$}

Bharti Hospital, Karnal, India

e-mail: brideknl@gmail.com

K. K. Shetty · V. B. Nagarajan · J. K. Ved

Boehringer Ingelheim Pvt Ltd, Mumbai, India
Keywords: Pharmaco-ergonomic qualification tool; Pharmaco-therapeutics; SGLT2 inhibitors; Pharmacovigilance; Reverse causality; Type 2 diabetes mellitus

\section{Key Summary Points}

This review is a comprehensive update on evidence-based therapeutic aspects of SGLT2 inhibitors, for heart failure, kidney disease, non-alcoholic fatty liver disease, type 1 diabetes mellitus, obesity, gout, syndrome of inappropriate ADH secretion (SIADH) and polycystic ovarian syndrome (PCOS)

The review attempts to facilitate optimum clinical decision-making regarding SGLT2 inhibitors through an updated pharmacoergonomic qualification tool

The review elaborates the clinically relevant aspects of safety and basic pharmacology for various SGLT2 inhibitors on the basis of contemporary evidence

This review summarizes the existing evidence, as well as ongoing studies, pertinent to SGLT2 inhibitors in various therapy areas 


\section{INTRODUCTION}

Sodium/glucose cotransporter 2 (SGLT2) inhibitors have opened up several aspects in clinical medicine, which now span beyond type 2 diabetes mellitus (T2DM). These clinical dimensions presently encompass metabolic, cardiovascular (CV) and renal therapeutics, and continue to evolve further. Simultaneously, the related aspects of pharmacovigilance and pharmaco-ergonomics of SGLT2 inhibitors have also witnessed continual progress.

A considerable part of the clinical development of SGLT2 inhibitors has not followed the typical evolutionary course of bench to bedside. Several key milestones, including CV protection and improved survival in EMPA-REG OUTCOME [1], risk of euglycemic diabetic ketoacidosis (euDKA) with SGLT2i class [2] and lower limb amputations in the CANVAS program [3], have been unexpected findings. Such important unexpected outcomes have prompted abductive reasoning and paved the way for the reverse developmental journey of SGLT2 inhibitors, from bedside to bench [4].

The typical developmental journey of these agents, from bench to bedside, has also witnessed distinctive outcomes. CREDENCE [5] and DAPA HF [6] established their clinical relevance in diabetic kidney disease and in heart failure with reduced ejection fraction, respectively. Their clinical development as anti-obesity agents has witnessed mixed outcomes $[7,8]$. The ongoing development will test the possible merit of SGLT2 inhibitors in non-diabetic kidney disease, heart failure with preserved ejection fraction, non-alcoholic fatty liver disease and possibly beyond.

Our previous review on this topic covered the pharmacological aspects of SGLT2 inhibitors, and corollary understanding of appropriate clinical use [9]. This review is a chronological update to our previous work; it focusses on the ongoing clinical developments of SGLT2 inhibitors, beyond their conventional role of glycaemia control in T2DM. The evidence-based perspectives are broadly classified into therapeutic area developments, pharmacovigilance, and rational pharmaco-ergonomics; each
Fig. 1 Comparison of cardiovascular outcomes in SGLT2i CVOTs. Direct comparison of studies should be interpreted with caution because of differences in study design, populations and methodology. a Major adverse cardiac event (MACE) outcomes. b Cardiovascular death outcomes. c Hospitalization for heart failure outcomes. MRF multiple risk factors, eCVD established cardiovascular disease. ${ }^{*} p$ value for interaction. d Kidney outcomes in SGLT2 inhibitor outcomes trials. *Accompanied by $\mathrm{eGFR} \leq 45 \mathrm{ml} / \mathrm{min} / 1.73 \mathrm{~m}^{2}$. ${ }^{\dagger}$ Nominal $p$ values. ${ }^{*}$ Sustained for at least 28 days. eGFR estimated glomerular filtration rate, ESKD end-stage kidney disease, ESRD endstage renal disease, NR not reported, PY patient-years, RRT renal replacement therapy, SGLTi sodium/glucose cotransporter 2 inhibitor, T2DM type 2 diabetes mellitus

section is further subclassified into experimental and clinical sections, as appropriate. This article is based on previously conducted studies and does not contain any studies with human participants or animals performed by any of the authors.

\section{THERAPY AREA DEVELOPMENTS}

In this section, we review the contemporary evidence of SGLT2 inhibitors in various therapy areas. These include cardiovascular medicine, nephrology, hepatology, diabetology, endocrinology and metabolism.

\section{Cardiovascular (CV) Medicine}

The clinical development of SGLT2 inhibitors in $\mathrm{CV}$ medicine spans across ischaemic heart disease, heart failure (HF) and hypertension.

\section{Clinical Evidence from Cardiovascular Outcome Trials (CVOTs)}

The chapter of SGLT2 inhibitors in CV medicine was driven by the remarkable unexpected findings from CVOTs. These CVOTs are designed to assess primarily the $\mathrm{CV}$ safety profiles of glucose-lowering interventions. The key observations from CVOTs are summarized in Fig. 1.

In 2015, the EMPA-REG OUTCOME study demonstrated significant benefits of empagliflozin for CV mortality, as well as major adverse 
(a) MACE Outcomes:

\begin{tabular}{|c|c|c|c|c|c|}
\hline \multirow{2}{*}{ Study } & \multicolumn{2}{|c|}{$\mathrm{n}$ event/ $\mathrm{N}$ analysed (\%) } & \multirow{2}{*}{$\begin{array}{c}\mathrm{HR} \\
(95 \% \mathrm{Cl})\end{array}$} & & \multirow{2}{*}{$p$-value } \\
\hline & SGLT2i & Placebo & & & \\
\hline $\begin{array}{l}\text { EMPA-REG OUTCOME } \\
(>99 \% \text { had eCVD })\end{array}$ & $\begin{array}{c}490 / 4687 \\
(10.5)\end{array}$ & $\begin{array}{c}282 / 2333 \\
(12.1)\end{array}$ & $\begin{array}{c}0.86 \\
(0.74,0.99)\end{array}$ & $\bullet$ & 0.04 \\
\hline $\begin{array}{l}\text { DECLARE-TIMI } 58^{2} \\
\text { Total population }\end{array}$ & $\begin{array}{c}756 / 8582 \\
(8.8)\end{array}$ & $\begin{array}{c}803 / 8578 \\
(9.4)\end{array}$ & $\begin{array}{c}0.93 \\
(0.84,1.03)\end{array}$ & $\mapsto$ & 0.17 \\
\hline MRF Subgroup & $\begin{array}{c}273 / 5108 \\
(5.3)\end{array}$ & $\begin{array}{c}266 / 5078 \\
(5.2)\end{array}$ & $\begin{array}{c}1.01 \\
(0.86,1.20)\end{array}$ & 0 & \\
\hline eCVD Subgroup & $\begin{array}{c}483 / 3474 \\
(13.9)\end{array}$ & $\begin{array}{c}537 / 3500 \\
(15.3)\end{array}$ & $\begin{array}{c}0.90 \\
(0.79,1.02)\end{array}$ & -هi- & $0.25^{*}$ \\
\hline $\begin{array}{l}\text { CANVAS Program } 3,4 \\
\text { Total population }\end{array}$ & $\begin{array}{l}585 / 5795 \\
(10.1)\end{array}$ & $\begin{array}{c}426 / 4347 \\
(9.9)\end{array}$ & $\begin{array}{c}0.86 \\
(0.75,0.97)\end{array}$ & - & 0.02 \\
\hline MRF Subgroup & - & - & $\begin{array}{c}0.98 \\
(0.74,1.30)\end{array}$ & 0 & \\
\hline \multirow[t]{2}{*}{ eCVD Subgroup } & - & - & $\begin{array}{c}0.82 \\
(0.72,0.95)\end{array}$ & 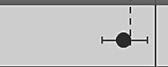 & $0.18^{*}$ \\
\hline & & & & $\stackrel{\text { Favours SGLT2i }}{0.5}^{1}$ & $\underset{\text { Favours placebo }}{\stackrel{2}{\longrightarrow}}$ \\
\hline
\end{tabular}

(b) Cardiovascular Death Outcomes:

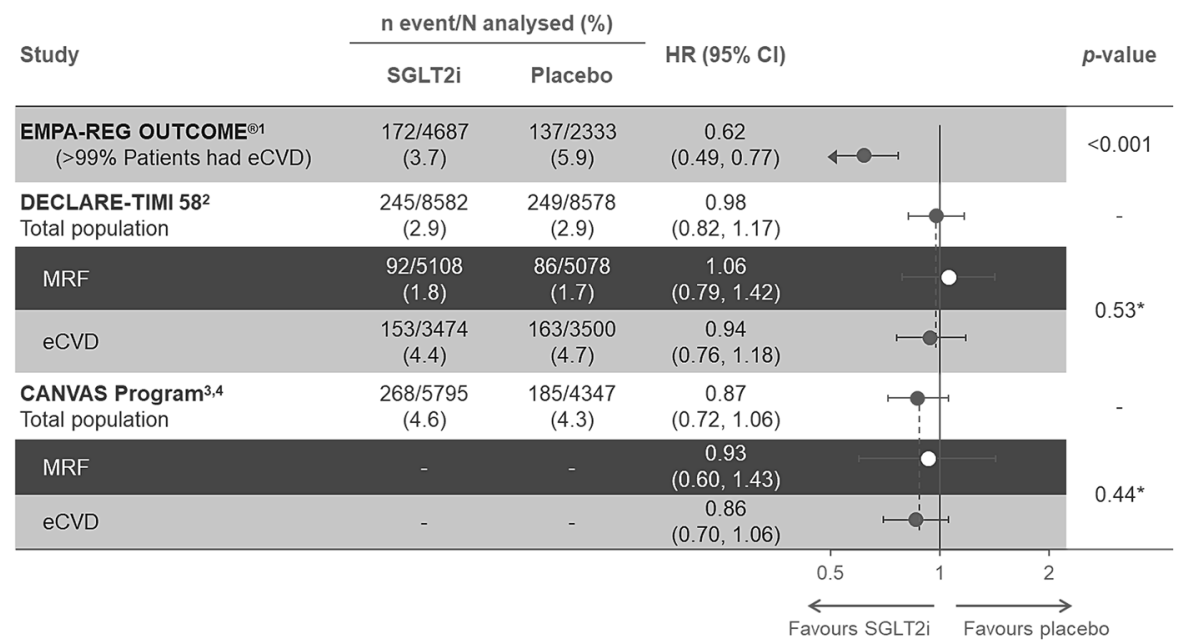

(c) Hospitalization for Heart Failure Outcomes:

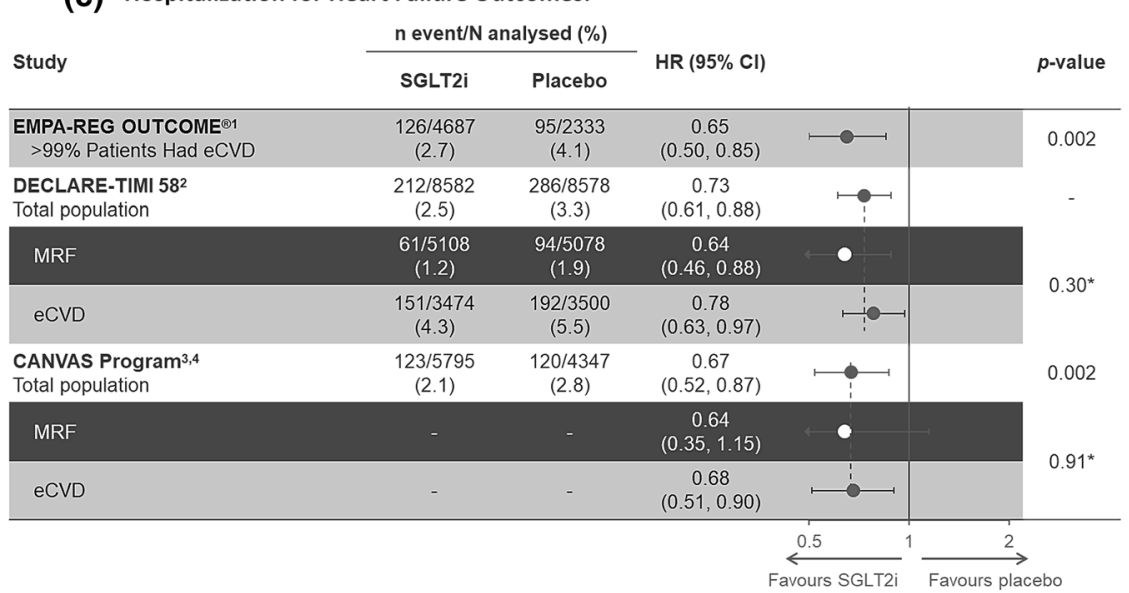

Direct comparison of studies should be interpreted with caution due to differences in study design, populations and methodology. MRF - Multiple Risk Factors; eCVD - established CVD * $p$-value for interaction. 
(d) Kidney Outcomes in SGLT2 inhibitor Outcomes Trials

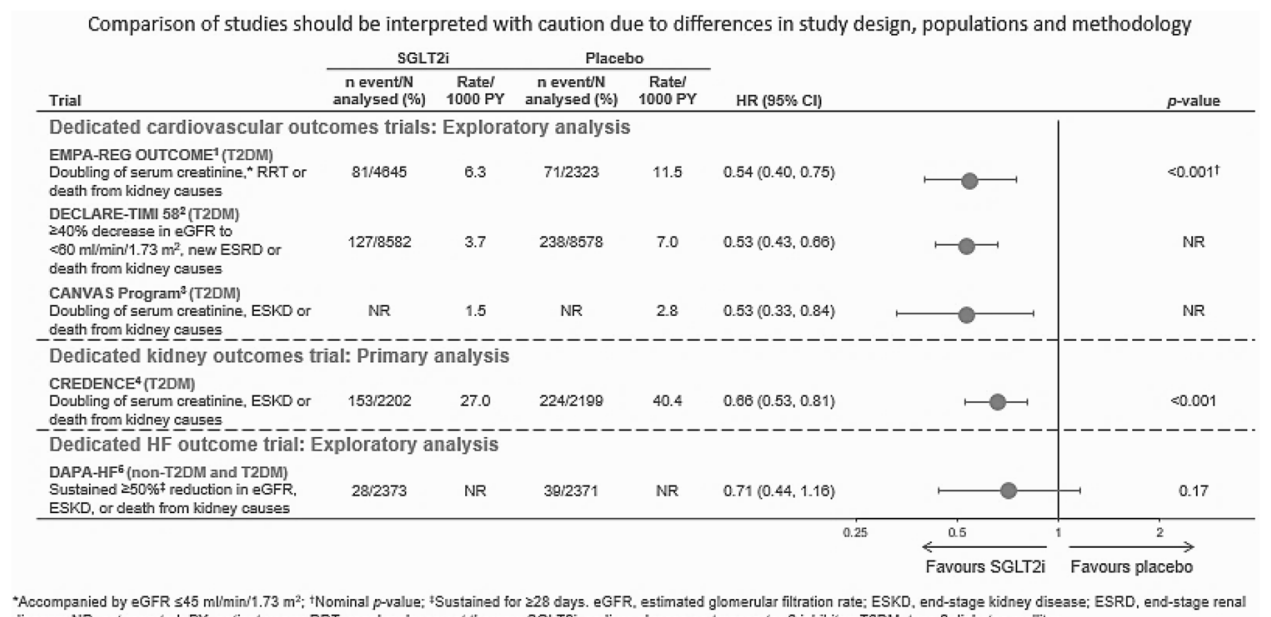

"Accompanied by eGFR $\leq 45 \mathrm{mlm} / \mathrm{min} / 1.73 \mathrm{~m}^{2}$; Nominal $p$-value; tSustained for 228 days. eGFR, estimated glomerular filtration rate: ESKD, end-stage kidney diseact

Fig. 1 continued

$\mathrm{CV}$ events, in patients with T2DM and CV disease [1]. These CV outcomes resulted in significant mortality benefit in these patients. All types of $\mathrm{CV}$ deaths were reduced with empagliflozin; more prominent absolute benefits were observed for HF-related deaths and sudden deaths [1]. The post hoc analyses of EMPA-REG OUTCOME demonstrated consistent CV mortality benefit with empagliflozin, irrespective of prior CV events (myocardial infarction or stroke), HF burden, chronic kidney disease (CKD), baseline HbA1c level, control of multiple CV risk factors or background use of metformin [10-13]. Moreover, a discordance between $\mathrm{CV}$ and glycaemic effects was evident; $\mathrm{CV}$ mortality benefit extended up to stage 3-b of CKD (eGFR up to $30 \mathrm{~mL} / \mathrm{min} / 1.73 \mathrm{~m}^{2}$ ). Further, unlike the dose-dependent incremental glycaemic effects of empagliflozin, both the clinical doses (10 mg and $25 \mathrm{mg}$ ) demonstrated equivalent $\mathrm{CV}$ benefits. With these observations, and the study design based on glycaemic equipoise, the CV mortality benefit was understood to be unrelated to the glucose-lowering effect of empagliflozin $[1,12]$. Subsequently, the CANVAS program also demonstrated reduction in risk of major adverse CV events with canagliflozin, in patients with T2DM and CV disease [14]. This benefit was not evident in patients without known CV disease, who harboured multiple CV risk factors, in the CANVAS program. The DECLARE-TIMI 58 study did not demonstrate significant reduction in major adverse CV events or CV mortality with dapagliflozin, in patients with T2DM and CV disease, or with multiple $\mathrm{CV}$ risk factors [15]. All these CVOTs demonstrated consistent improvements in HF-related outcomes with SGLT2i agents. These HF benefits were observed in patients with or without prior HF [16].

\section{Bedside to Bench: Evidence from Experimental Research}

Following these unexpected findings from CVOTs, wide-ranging experimental research was initiated to evaluate the plausible $\mathrm{CV}$ mechanisms. Through this spectrum of research, several corollary effects of renal SGLT2 inhibition of the cardiovascular system have been proposed and/or discovered. Further, a new site of action for these agents has also been discovered in non-clinical studies, viz. sodium/ hydrogen exchanger 1 (NHE-1) in cardiomyocytes [17-19].

This experimental research includes nonclinical as well as clinical studies and has been recently reviewed. The plausible $\mathrm{CV}$ mechanisms have been broadly classified as effects on preload, afterload, as well as at the heart level. Figure 2 gives an overview of these mechanisms. 
It is noteworthy that while non-clinical research may have demonstrated some effects, the same may or may not be replicable in humans. Thus, a conclusive human proof-ofconcept study is essential to affirm the clinical relevance of any foundational therapeutic concept. On these lines, the recently published EMPA-HEART study was a randomized controlled trial (RCT) in patients with T2DM and stable coronary artery disease (CAD), largely without HF [20]. This study demonstrated regression in left ventricular mass index with empagliflozin, over 6 months. This effect was unrelated to reduction in preload, blood pressure or autonomic changes [20-22]. This proofof-concept suggests beneficial effects of empagliflozin on left ventricular myocardial structure in patients with T2DM, with stable CAD and without HF. These beneficial myocardial effects may possibly benefit patients with ischaemic heart disease, beyond the HF-related mechanisms.

\section{Clinical Development in HF (Chronic, Post- Acute)}

Early interest in SGLT2 inhibitors for HF stemmed from the mechanism of glucose-mediated osmotic diuresis, and unexpected HF benefit in EMPA-REG OUTCOME. Pharmacodynamic studies have shown that even in healthy adults without type 2 diabetes, SGLT2 inhibitors mediate a modest urinary glucose elimination of 40-50 g/day [23, 24]. Further, several mechanisms have been elicited in non-clinical experiments, as summarized in Fig. 2. A post hoc analysis of EMPA-REG OUTCOME also suggested clinical benefits in rehospitalizations and mortality, in the post-acute HF period [25].

These agents are being clinically studied for several outcomes related to chronic HF and post-acute HF, regardless of T2DM [24, 26]. These outcomes include hospitalizations, mortality, functional exercise capacity, and quality of life in patients with chronic HF and reduced or preserved ejection fraction (EF). Further, these are also being evaluated for outcomes of rehospitalization/mortality risk reduction in post-acute HF. The DAPA-HF study has demonstrated improved HF and mortality outcomes with dapagliflozin in patients with chronic HF and reduced EF, with or without T2DM [6]. A summary of ongoing studies is described in Tables 1 and 2.

The phenomenon of reverse causality may be of noteworthy relevance in SGLT2 inhibitor therapeutics [27]. While ischaemic CV benefits may result from improvements in left ventricular mass, vascular stiffness, blood pressure and myocardial metabolism, such benefits would need longer duration to manifest. The haemodynamic benefits of these agents on HF and renal outcomes are more immediate in nature. Hence, with considerable haemodynamic benefits occurring early, the possible late-onset ischaemic CV benefits can get masked because of survivorship bias, particularly when mortality is reduced early. EMPA-REG OUTCOME, CANVAS program and CREDENCE have demonstrated benefits in major adverse cardiovascular events with these agents in various study populations, whereas DECLARE-TIMI 58 did not demonstrate such benefit, except in a post hoc analysis of a subgroup with prior myocardial infarction $[1,5,14,15,28]$.

\section{Clinical Evidence in Hypertension}

Modest reductions in systolic and diastolic blood pressure have been well recognized in clinical development of SGLT2 inhibitors [9]. While the mechanism of diuresis may lead to immediate antihypertensive effect, other mechanisms like improvement in vascular stiffness may also play a key role. The diuretic mechanism of SGLT2 inhibitors is different from the classic natriuretic diuresis $[19,29]$. SGLT2i-mediated osmotic diuresis leads to more electrolyte-free water clearance, which effects more prominent fluid loss from interstitial spaces. This is unlike the typical natriuretic diuretics, which exert a greater effect on blood volume loss, driven by sodium elimination. The net loss of blood volume prompts compensatory activation of sympathetic activity and plasma renin activity. Such compensatory effects are infrequently observed with SGLT2 inhibitors. Further, neurohumoral effects of reduced angiotensin or sympathetic activity do not explain the improvement in vascular compliance with SGLT2 inhibitors. The present evidence suggests that these effects are 
(a) Glucose-mediated Osmotic Diuresis

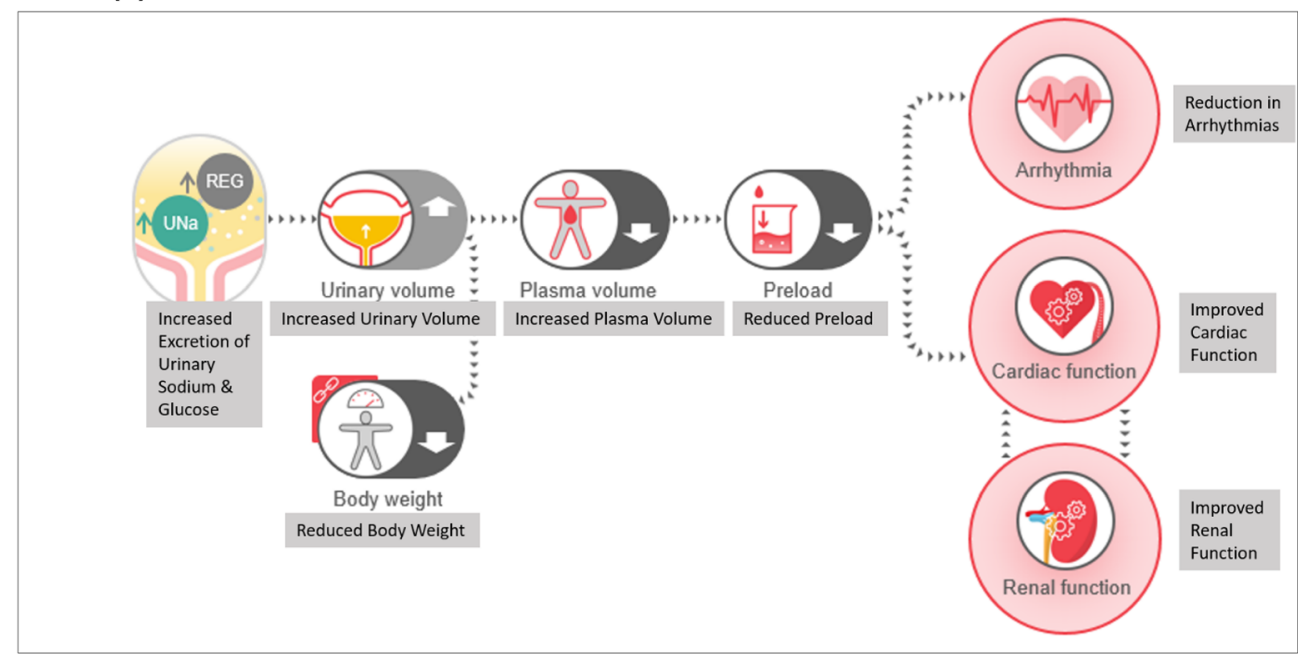

(b) Neuro-hormonal Response with SGLT2-inhibitors

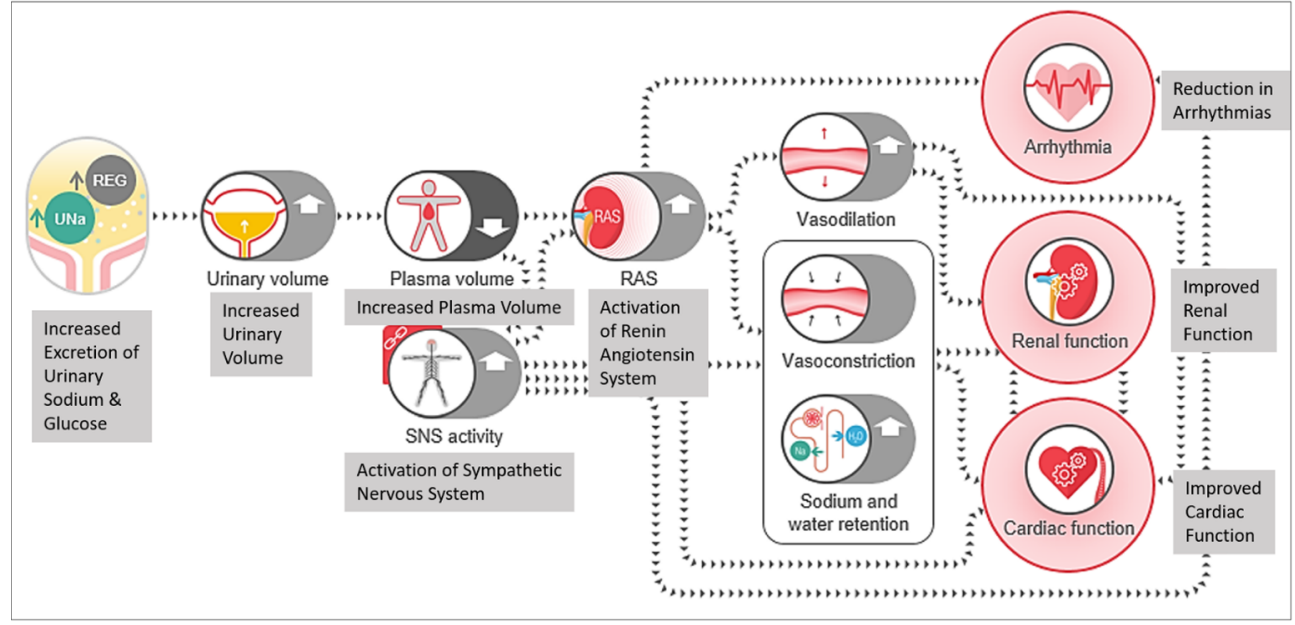

(c) Afterload reduction and Increased Oxygen Delivery

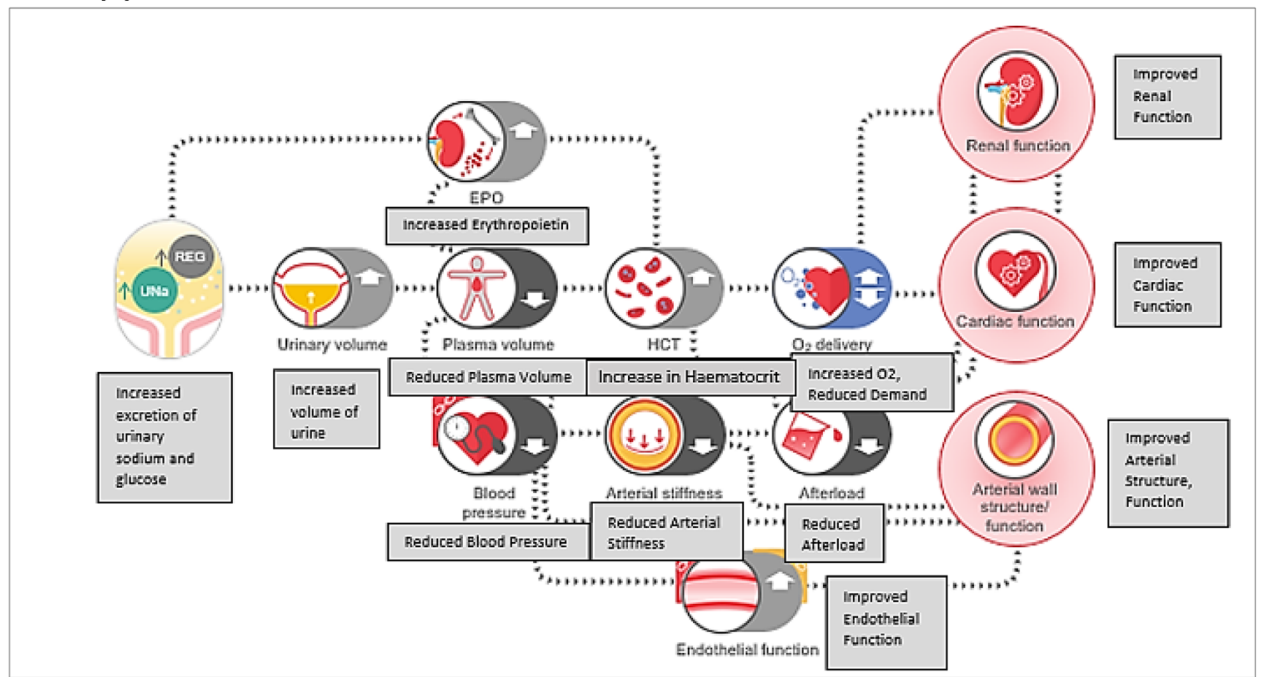


4Fig. 2 Mechanisms of empagliflozin

mediated at the level of blood vessels, through improved vascular endothelial and smoothmuscle functioning $[17,19,30]$.

More recently, the possible role of SGLT2 inhibitors in controlling difficult cases of hypertension, including nocturnal non-dipping and resistant hypertension, is being increasing realized [31-33].

Nocturnal hypertension is an independent risk factor for adverse CV outcomes. The SACRA study demonstrated that in patients with T2DM and nocturnal hypertension, empagliflozin significantly reduced nocturnal blood pressure from baseline [31]. This may be a meaningful benefit in patients with salt-sensitive nocturnal hypertension.

A post hoc analysis of EMPA-REG OUTCOME demonstrated consistent reductions in blood pressure in patients with resistant hypertension [32]. An interesting case report demonstrated clinical benefit of canagliflozin in a patient with resistant hypertension, which was uncontrolled even after renal denervation [33]. This case report suggested the importance of ineffective diuresis in resistant hypertension and the relevance of canagliflozin in overcoming the natriuretic handicap. This is an area of therapeutic interest, which clearly deserves more research.

\section{Nephrology}

Nephrology is another area of immense clinical value for SGLT2 inhibitors. These drugs may be of benefit by delaying the decline of renal function, reducing risk of end-stage kidney disease and renal deaths.

The presently known CVOTs of SGLT2 inhibitors have consistently shown renal benefits in patients with T2DM [16]. There are multiple possible mechanisms through which SGLT2 inhibitors may improve renal dysfunction; some of these have been proven in clinical proof-of-concept studies [34].

\section{Evidence from Pharmacodynamic and Mechanistic Studies}

Kidneys are involved in glucose metabolism through renal gluconeogenesis as well as glucose reabsorption [35]. While gluconeogenesis is the major mechanism, it does not contribute significantly to blood glucose levels because the kidneys also require considerable glucose consumption to maintain their function. On the other hand, glucose reabsorption can significantly contribute to glycaemia levels, particularly during states of increased glucose reabsorption like diabetes. Increased proximal tubular glucose flux, which typically happens in diabetes, increases SGLT2 transporter expression and function in renal tubules. Elevated SGLT2 transporter function is also known to increase sodium reabsorption, resulting in tubulo-glomerular feedback and hyperfiltration. The relevance of SGLT2 inhibitors in ameliorating this tubulo-glomerular feedback has received much clinical interest [34, 36, 37]. Apart from this, several mechanisms like improved renal metabolism, reduced uric acid level, downregulation of sodium/hydrogen exchanger 3 (NHE-3), and neurohumoral modulation are being explored [34, 36, 37].

\section{Evidence from Clinical Trials}

CREDENCE, a dedicated renal outcome trial in patients with advanced proteinuric diabetic kidney disease, demonstrated significant improvements in renal outcomes with canagliflozin [5]. The value of SGLT2 inhibitors in non-diabetic kidney disease is a futuristic topic of interest. Ongoing EMPA-KIDNEY [38] and DAPA-CKD [39] studies will evaluate the effect of these agents in patients with non-diabetic kidney disease. Table 3 shows an overview of these trials.

SGLT2 inhibitors also increase haematocrit, likely through an increase in erythropoiesis. A probable explanation for this effect is based on reduced metabolic stress in proximal tubular epithelial cells, secondary to reduced activity of sodium-potassium ATPase pump. This optimum milieu stimulates erythropoiesis from mesenchymal fibroblasts by partly reversing the early derangements of CKD [40]. A corollary benefit of this mechanism could be plausible in anaemia of $\mathrm{CKD}$, with reduction in dose of 
(d) Haemodynamic improvement through renal volume regulation

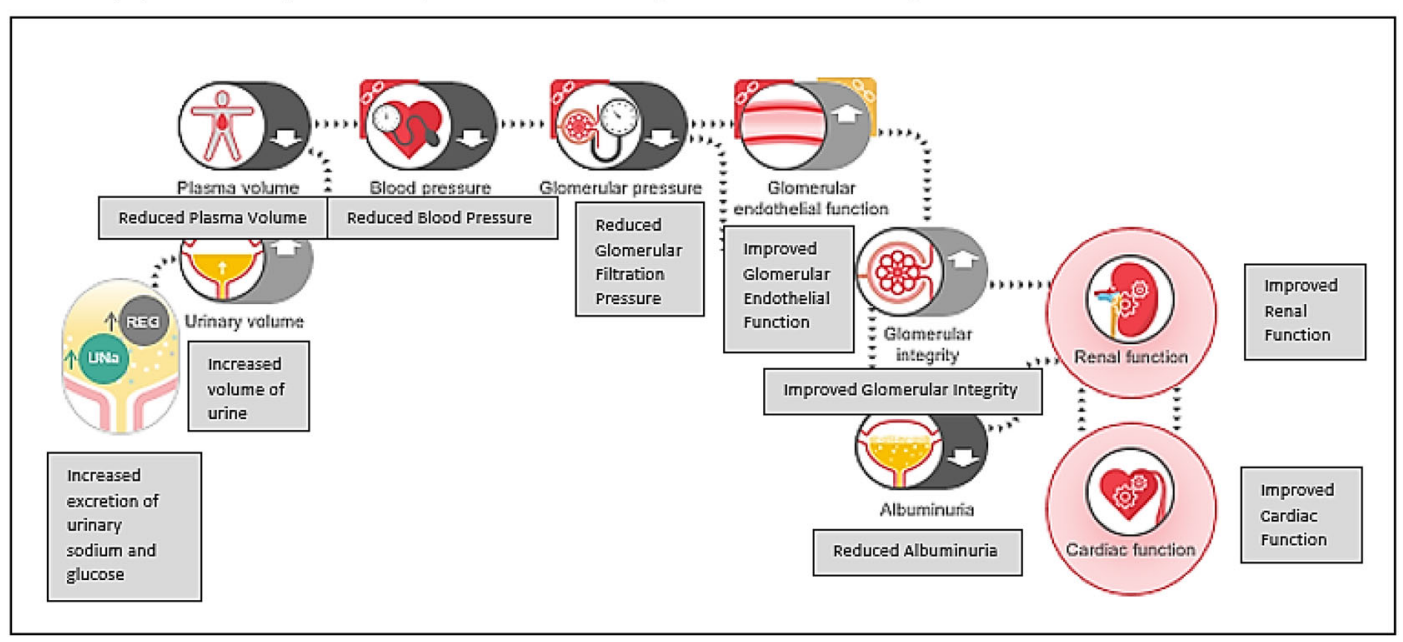

(e) Lowering of Plasma Uric Acid Level

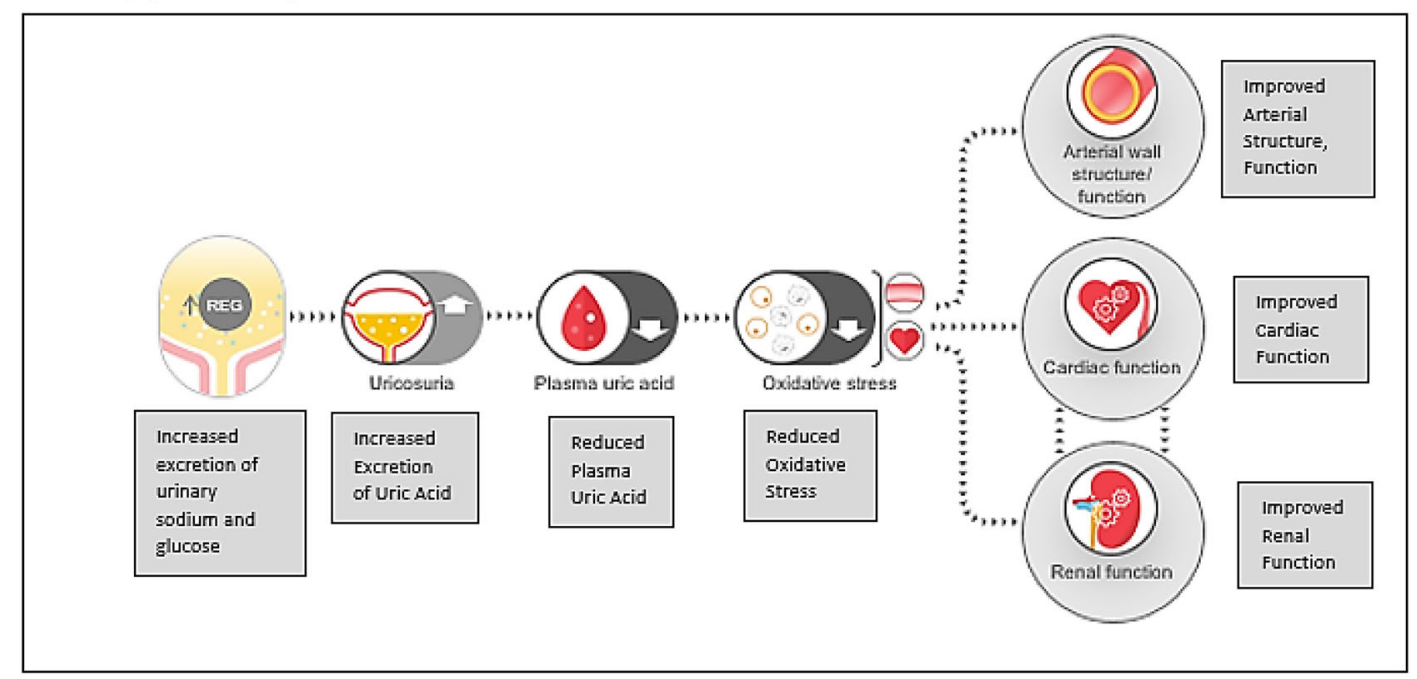

(f) Inhibition of $\mathrm{Na}^{+} / \mathrm{H}^{+}$Exchanger (NHE-1) on Myocardial Cells

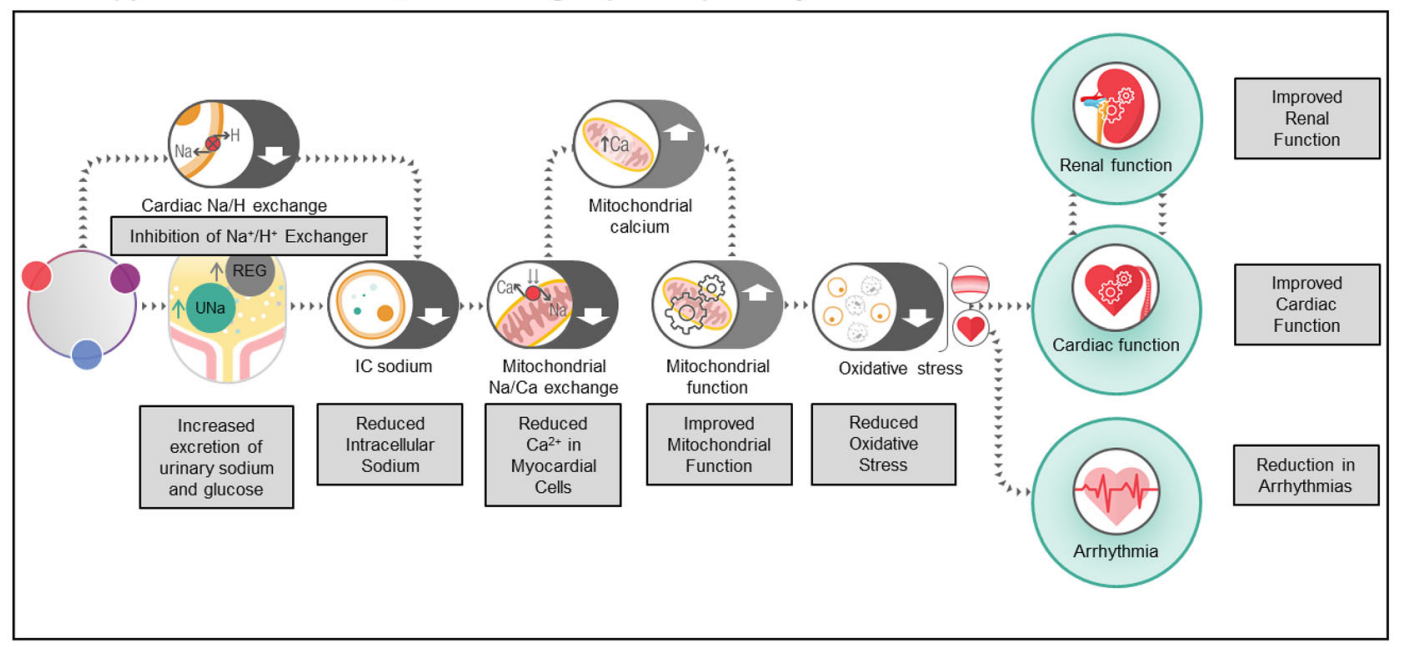




\section{(g) Correction of Renal Tubulo-glomerular Feedback}

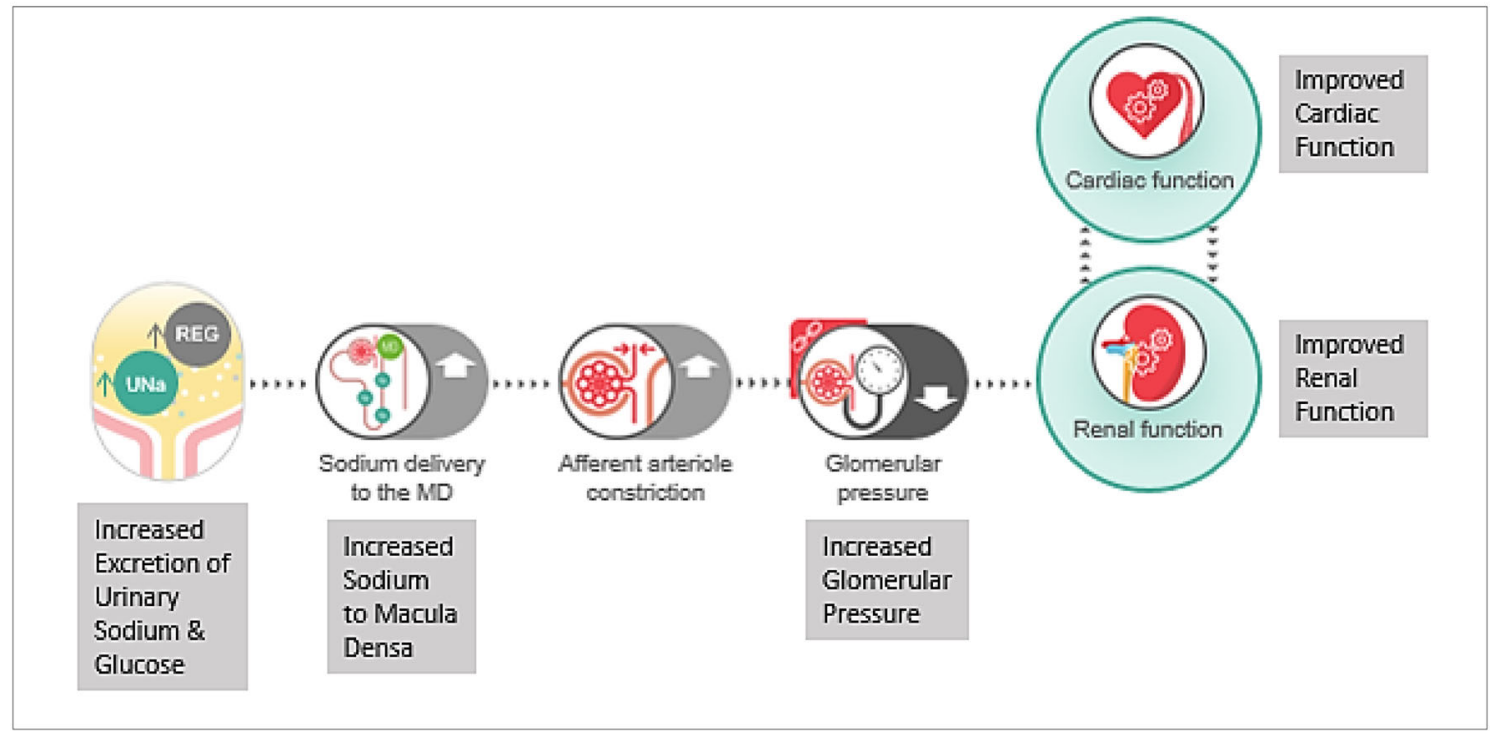

Fig. 2 continued

erythropoietin-stimulating agents. The present evidence for this benefit is scarce and requires substantiation.

\section{Hepatology}

A corollary effect of visceral adipose tissue reduction with SGLT2 inhibitors is a reduction in hepatic steatosis [41]. Non-alcoholic fatty liver disease (NAFLD) is of common occurrence in T2DM and has important associations with hepatic cirrhosis, portal hypertension, hepatocellular carcinoma and mortality. However, from a practical viewpoint, clinical development aimed at demonstrating NAFLD benefit cannot evaluate terminal outcomes that develop over years. At present, reliable surrogate outcomes for clinically meaningful NAFLD

Table 1 Comparison of SGLT2 inhibitor trials on functional outcomes and quality of life in patients with chronic heart failure

\begin{tabular}{|c|c|c|c|c|}
\hline & $\begin{array}{l}\text { EMPERIAL- } \\
\text { Preserved }\end{array}$ & $\begin{array}{l}\text { EMPERIAL- } \\
\text { Reduced }\end{array}$ & $\begin{array}{l}\text { DETERMINE- } \\
\text { Preserved }\end{array}$ & $\begin{array}{l}\text { DETERMINE- } \\
\text { Reduced }\end{array}$ \\
\hline Study drug & \multicolumn{2}{|c|}{ Empagliflozin $10 \mathrm{mg}$ qd } & \multicolumn{2}{|l|}{ Dapagliflozin 10 mg qd } \\
\hline Sample size & 300 & 300 & 400 & 300 \\
\hline \multirow{3}{*}{$\begin{array}{l}\text { Key inclusion } \\
\text { criteria }\end{array}$} & \multicolumn{2}{|c|}{ Chronic HF NYHA class II-IV } & \multicolumn{2}{|c|}{ Chronic HF NYHA class II-IV } \\
\hline & \multicolumn{2}{|c|}{ Walking distance in the $6 \mathrm{MWT} \leq 350 \mathrm{~m}$} & \multicolumn{2}{|c|}{$\begin{array}{l}\text { Walking distance in the 6MWT } \geq 100 \text { to } \\
\leq 425 \mathrm{~m}\end{array}$} \\
\hline & $\begin{array}{l}\mathrm{HFpEF} \\
\qquad(\mathrm{LVEF}>40 \%)\end{array}$ & $\begin{array}{l}\mathrm{HFrEF} \\
\qquad(\mathrm{LVEF} \leq 40 \%)\end{array}$ & HFpEF (LVEF > 40\%) & HFrEF $($ LVEF $\leq 40 \%)$ \\
\hline \multirow[t]{2}{*}{ Primary endpoint } & \multicolumn{2}{|c|}{ Change from baseline to week 12} & \multicolumn{2}{|c|}{ Change from baseline to week 16} \\
\hline & \multicolumn{2}{|c|}{ in exercise capacity (6MWT) } & \multicolumn{2}{|c|}{ in exercise capacity (6MWT) } \\
\hline
\end{tabular}

NYHA New York Heart Association, 6MWT 6-min walk test, $H F p E F$ heart failure with preserved ejection fraction, $H F r E F$ heart failure with reduced ejection fraction, $L V E F$ left ventricular ejection fraction 
Table 2 Comparison of SGLT2 inhibitor trials on heart failure with or without T2DM

\begin{tabular}{|c|c|c|c|c|c|}
\hline & EMPULSE & DELIVER & SOLOIST-WHF & CHIEF-HF & EMPEROR \\
\hline Study drug & Empagliflozin $10 \mathrm{mg}$ & $\begin{array}{l}\text { Dapagliflozin } \\
10 \mathrm{mg}\end{array}$ & Sotagliflozin & Canagliflozin & $\begin{array}{l}\text { Empagliflozin } \\
10 \mathrm{mg}\end{array}$ \\
\hline Population & $\begin{array}{l}\text { Acute but stabilized heart } \\
\text { failure with or without } \\
\text { T2DM }\end{array}$ & $\begin{array}{l}\text { HFpEF in } \\
\text { patients with } \\
\text { or without } \\
\text { T2DM }\end{array}$ & $\begin{array}{l}\text { Worsening HF in } \\
\text { patients with T2D }\end{array}$ & $\begin{array}{l}\text { Patients with } \\
\text { heart failure, } \\
\text { with or } \\
\text { without T2D }\end{array}$ & $\begin{array}{l}\text { HF with } \\
\text { preserved or } \\
\text { reduced } \mathrm{EF} \text {, } \\
\text { with or } \\
\text { without T2D }\end{array}$ \\
\hline \multirow[t]{2}{*}{ Sample size } & 500 & 4700 & 6667 & 1900 & 5500 (preserved) \\
\hline & & & & & 3350 (reduced) \\
\hline \multirow{7}{*}{$\begin{array}{l}\text { Key } \\
\text { inclusion } \\
\text { criteria }\end{array}$} & Elevated NT-proBNP & Symptomatic & T2DM & & Chronic HF \\
\hline & $\begin{array}{l}\text { Hospital admission for } \\
\text { worsening HF and }\end{array}$ & $\begin{array}{c}\text { HFpEF } \\
\text { Elevated NT- }\end{array}$ & $\begin{array}{l}\text { Elevated NT- } \\
\text { proBNP }\end{array}$ & & $\begin{array}{l}\text { (NYHA class } \\
\text { II-IV) }\end{array}$ \\
\hline & $\begin{array}{l}\text { haemodynamically } \\
\text { stable }\end{array}$ & $\begin{array}{l}\text { proBNP } \\
\text { eGFR } \geq 25 \mathrm{ml} /\end{array}$ & $\begin{array}{l}\text { Hospital admission } \\
\text { for worsening HF }\end{array}$ & & $\begin{array}{l}\text { Elevated NT- } \\
\text { proBNP }\end{array}$ \\
\hline & Patients with HFrEF & $\min / \overline{1.73} \mathrm{~m}^{2}$ & & & $\mathrm{eGFR} \geq 20 \mathrm{ml} /$ \\
\hline & $\begin{array}{l}\text { administered loop } \\
\text { diuretics (unless }\end{array}$ & $\begin{array}{l}\text { Ambulatory and } \\
\text { hospitalized }\end{array}$ & $\begin{array}{l}\text { haemodynamically } \\
\text { stable }\end{array}$ & & $\min / 1.73 \mathrm{~m}^{2}$ \\
\hline & contraindicated) & patients & $\begin{array}{l}\text { Patients with } \\
\text { HFrEF } \\
\text { administered beta- } \\
\text { blockers and } \\
\text { RAAS inhibitors } \\
\text { (unless } \\
\text { contraindicated) }\end{array}$ & & \\
\hline & $\begin{array}{l}\text { HFpEF and HFrEF } \\
(\mathrm{LVEF}<40 \%)\end{array}$ & $\begin{array}{l}\text { HFpEF } \\
\quad(\mathrm{LVEF}>40 \%)\end{array}$ & $\begin{array}{l}\text { HFpEF and HFrEF } \\
(\mathrm{LVEF}<50 \%)\end{array}$ & $\begin{array}{l}\text { HFpEF and } \\
\text { HFrEF } \\
\quad(\mathrm{LVEF}<40 \%)\end{array}$ & $\begin{array}{l}\text { HFpEF and } \\
\text { HFrEF } \\
(\text { LVEF }<40 \%)\end{array}$ \\
\hline $\begin{array}{l}\text { Primary } \\
\text { endpoints }\end{array}$ & $\begin{array}{l}\text { Net clinical benefit, a } \\
\text { composite of all-cause } \\
\text { mortality, number of } \\
\text { heart failure events } \\
\text { (including } \\
\text { hospitalizations, urgent } \\
\text { heart failure visits and } \\
\text { unplanned patient } \\
\text { visits), time to first } \\
\text { heart failure event and } \\
\text { change from baseline } \\
\text { in Kansas City } \\
\text { Cardiomyopathy } \\
\text { Questionnaire }\end{array}$ & $\begin{array}{l}\text { Time to first } \\
\text { occurrence of } \\
\text { CV death, } \\
\text { HHF or urgent } \\
\text { HF visit }\end{array}$ & $\begin{array}{l}\text { Time to first } \\
\text { occurrence of } \\
\text { either CV death } \\
\text { or HHF in } \\
\text { patients with } \\
\text { LVEF }<50 \% \\
\text { Time to first } \\
\text { occurrence of } \\
\text { either CV death or } \\
\text { HHF in the total } \\
\text { patient population }\end{array}$ & & $\begin{array}{l}\text { Time to first } \\
\text { event of } \\
\text { adjudicated CV } \\
\text { death or } \\
\text { adjudicated } \\
\text { HHF }\end{array}$ \\
\hline
\end{tabular}

NYHA New York Heart Association, $H F p E F$ heart failure with preserved ejection fraction, $H F r E F$ heart failure with reduced ejection fraction, $L V E F$ left ventricular ejection fraction, $H H F$ hospitalization for heart failure, $R A A S$ renin-angiotensin-aldosterone system 
Table 3 Comparison of renal outcome trials with SGLT2 inhibitors

\begin{tabular}{|c|c|c|c|}
\hline & CREDENCE & DAPA-CKD & EMPA-KIDNEY \\
\hline $\begin{array}{l}\text { SGLT2 } \\
\text { inhibitor }\end{array}$ & Canagliflozin vs placebo & Dapagliflozin vs placebo & Empagliflozin vs placebo \\
\hline Population & $\begin{array}{l}\text { Diabetic kidney disease, } \\
\text { including } \\
x \text { T2DM } \\
x \text { Non-DM } \\
x \text { T1DM }\end{array}$ & $\begin{array}{l}\text { Chronic kidney disease, including } \\
\boldsymbol{\sim} \text { T2DM } \\
\boldsymbol{\sim} \text { Non-DM } \\
\boldsymbol{x} \text { T1DM }\end{array}$ & $\begin{array}{l}\text { Chronic kidney disease, including } \\
\boldsymbol{\swarrow} \text { T2DM } \\
\boldsymbol{\swarrow} \text { Non-DM } \\
\boldsymbol{\swarrow T 1 D M}\end{array}$ \\
\hline $\begin{array}{l}\text { No. of } \\
\text { patients }\end{array}$ & 4401 & 4000 & ca. 5000 \\
\hline $\begin{array}{l}\text { Key } \\
\text { inclusion } \\
\text { criteria }\end{array}$ & $\begin{array}{l}\mathrm{eGFR} \geq 30 \text { to }<90 \mathrm{ml} / \\
\mathrm{min} / 1.73 \mathrm{~m}^{2} \text { and } \\
\mathrm{UACR}>300 \mathrm{mg} / \mathrm{g}\end{array}$ & $\begin{array}{l}\mathrm{eGFR} \geq 25 \text { to } \leq 75 \mathrm{ml} / \mathrm{min} / \\
1.73 \mathrm{~m}^{2} \text { and } \mathrm{UACR} \geq 200 \mathrm{mg} / \\
\mathrm{g}\end{array}$ & $\begin{array}{c}\mathrm{eGFR} \geq 20 \text { to }<45 \mathrm{ml} / \mathrm{min} / 1.73 \mathrm{~m}^{2} \\
\text { or } \mathrm{eGFR} \geq 45 \text { to }<90 \mathrm{ml} / \mathrm{min} / \\
1.73 \mathrm{~m}^{2} \text { and } \mathrm{UACR} \geq 200 \mathrm{mg} / \mathrm{g}\end{array}$ \\
\hline $\begin{array}{l}\text { Primary } \\
\text { outcome }\end{array}$ & $\begin{array}{l}\text { Composite of ESKD, } \\
\text { doubling of serum } \\
\text { creatinine, or renal or } \\
\text { CV death }\end{array}$ & $\begin{array}{l}\text { Composite of } \geq 50 \% \text { sustained } \\
\text { decline in eGFR or reaching } \\
\text { ESKD, or renal or CV death }\end{array}$ & $\begin{array}{l}\text { Composite of } \geq 40 \% \text { sustained decline } \\
\text { in eGFR or reaching ESKD, or renal } \\
\text { or CV death }\end{array}$ \\
\hline $\begin{array}{l}\text { Key } \\
\text { secondary } \\
\text { outcomes }\end{array}$ & $\begin{array}{l}\text { Composite of CV death or } \\
\text { HHF } \\
\text { All-cause mortality }\end{array}$ & $\begin{array}{l}\text { Composite of } \mathrm{CV} \text { death or } \mathrm{HHF} \\
\text { All-cause mortality }\end{array}$ & $\begin{array}{l}\text { Composite of } \mathrm{CV} \text { death or } \mathrm{HHF} \\
\text { All-cause hospitalization } \\
\text { All-cause mortality }\end{array}$ \\
\hline
\end{tabular}

$\overline{T 1 D M}$ type 1 diabetes mellitus, $U A C R$ urine albumin to creatinine ratio, ESKD end-stage kidney disease, $H H F$ hospitalization for heart failure

benefit are limited to resolution of non-alcoholic steatohepatitis (NASH) or improvement in fibrosis without worsening of NASH. Mere reduction in hepatic steatosis is not a reliable outcome for clinically meaningful NAFLD benefit [42].

The investigator-initiated E-LIFT study of empagliflozin furnished early clinical evidence in patients with T2DM and NAFLD [43]. The study demonstrated reduction in hepatic steatosis as well as aminotransferase levels with 20 weeks of empagliflozin therapy. Further proof-of-concept studies with dapagliflozin, canagliflozin, luseogliflozin and ipragliflozin have also demonstrated similar results of improved hepatic steatosis and aminotransferases [41]. A case series in patients with NASH demonstrated that 24-week treatment with canagliflozin resulted in histopathologic improvement (decrease in NAS of 1 point or more without worsening of the fibrosis stage) [44]. A further extension of this work suggested improved scores of steatosis, lobular inflammation, ballooning and fibrosis stage [45]. Small studies of SGLT2 inhibitors based on markers for hepatic fibrosis have demonstrated mixed results [41]. At present, conclusive evidence for clinically meaningfully benefit in NASH, based on hard outcomes or appropriate surrogate outcomes, is unavailable with any SGLT2 inhibitor. This remains an area of immense clinical interest.

\section{Diabetes}

SGLT2 inhibitors have been evaluated in dedicated programs for type 1 diabetes mellitus 


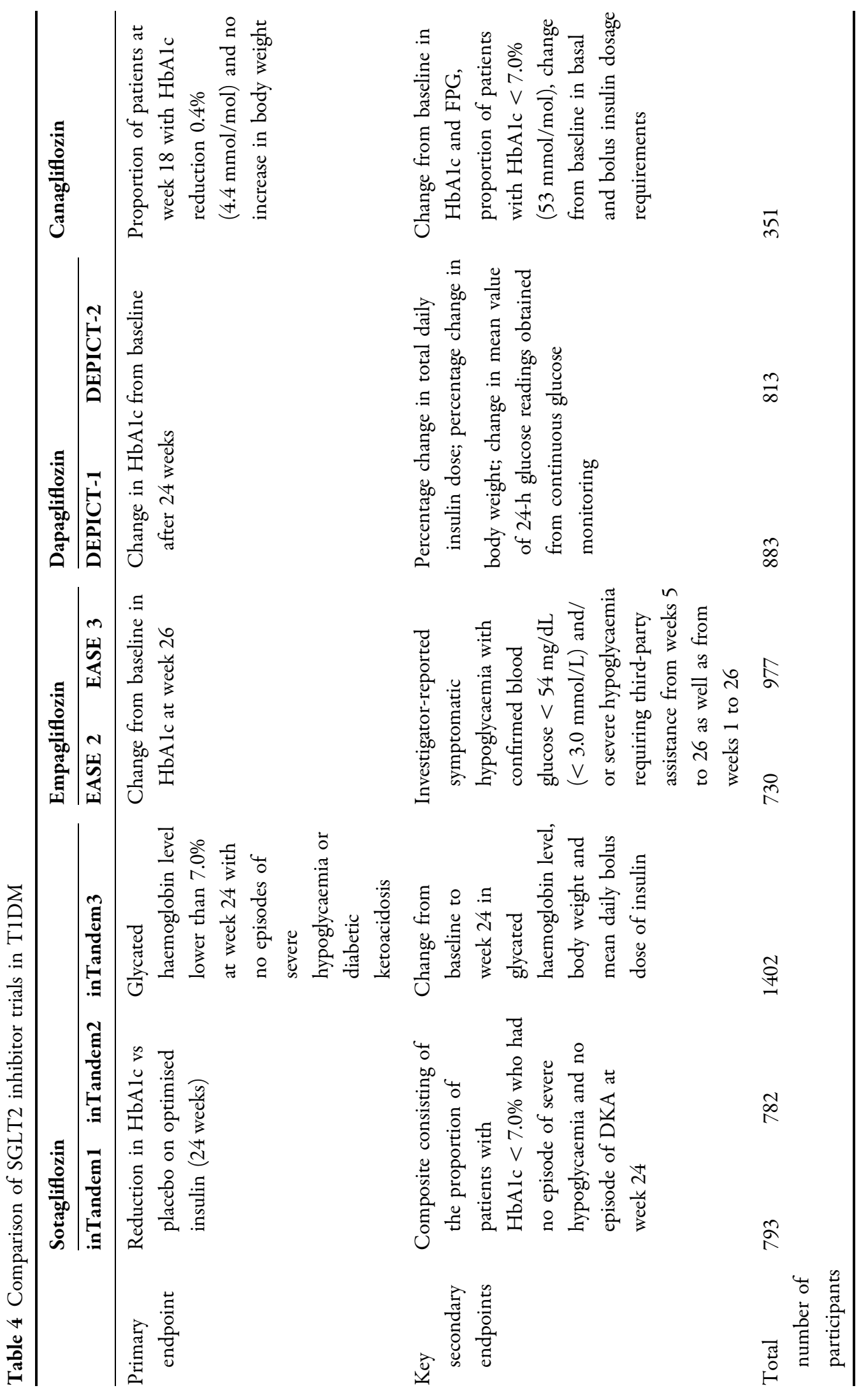




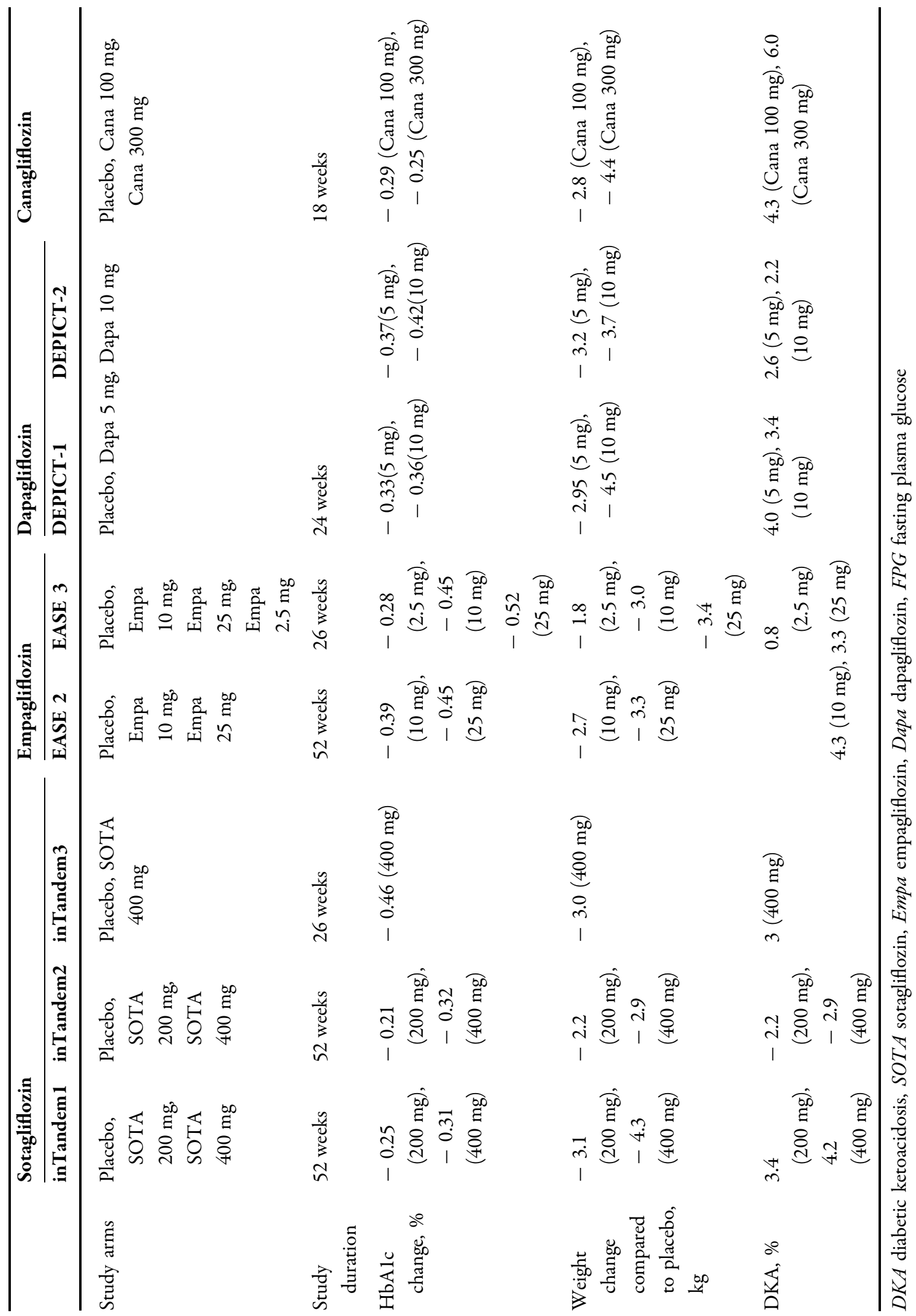


Table 5 Comparison of safety based on SGLT2 inhibitor CV outcome trials

\begin{tabular}{|c|c|c|c|c|c|c|}
\hline & $\begin{array}{l}\text { Placebo } \\
(n=2333) \\
n(\%)\end{array}$ & $\begin{array}{l}\text { Pooled } \\
\text { empagliflozin } \\
(n=4687) \\
n(\%)\end{array}$ & $\begin{array}{l}\text { Placebo } \\
(n=8569) \\
n(\%)\end{array}$ & $\begin{array}{l}\text { Dapagliflozin } \\
(n=8574) \\
n(\%)\end{array}$ & $\begin{array}{l}\text { Placebo } \\
\text { Event rate per } \\
1000 \mathrm{PY}\end{array}$ & $\begin{array}{l}\text { Canagliflozin } \\
\text { Event rate per } \\
1000 \mathrm{PY}\end{array}$ \\
\hline Hypoglycaemia & $650(27.9)$ & $1303(27.8)$ & NR & NR & 16.4 & 50.0 \\
\hline $\begin{array}{l}\text { Requiring } \\
\text { assistance }\end{array}$ & $36(1.5)$ & $63(1.3)$ & $83(1.0)$ & $58(0.7)$ & NR & NR \\
\hline DKA & $1(<0.1)$ & $4(0.1)$ & $12(0.2)$ & $27(0.3)$ & 0.3 & 0.6 \\
\hline UTI & $423(18.1)$ & $842(18.0)$ & $133(1.6)$ & $127(1.5)$ & 37.0 & 40.0 \\
\hline $\begin{array}{l}\text { Genital } \\
\text { infection }\end{array}$ & $42(1.8)$ & $301(6.4)$ & $9(0.1)$ & $76(0.9)$ & 10.8 & 34.9 \\
\hline $\begin{array}{l}\text { Volume } \\
\text { depletion }\end{array}$ & $115(4.9)$ & $239(5.1)$ & $207(2.4)$ & $213(2.5)$ & 18.5 & 26.0 \\
\hline Bone fractures & $91(3.9)$ & $179(3.8)$ & $440(5.1)$ & $457(5.3)$ & 11.9 & 15.4 \\
\hline $\begin{array}{l}\text { Acute kidney } \\
\text { injury }\end{array}$ & $37(1.6)$ & $45(1.0)$ & $175(2.0)$ & $125(1.5)$ & 4.1 & 3.0 \\
\hline $\begin{array}{l}\text { Lower limb } \\
\text { amputation }\end{array}$ & $43(1.8)$ & $44(1.9)$ & $113(1.3)$ & $123(1.4)$ & 3.37 & 6.30 \\
\hline
\end{tabular}

$U T I$ urinary tract infection, $P Y$ patient-year, $N R$ not reported

(T1DM). Several SGLT2i studies have demonstrated efficacy outcomes, like improved glycaemia control and reduced insulin dose requirements in T1DM [46-54]. However, the safety concern of euDKA, which is of even greater relevance in T1DM, remains a major barrier to be negotiated. A unique pharmacological strategy of using low dose empagliflozin $(2.5 \mathrm{mg})$ to optimize the risk-benefit profile in T1DM has been evaluated [52]. Further evidence in this direction may suggest the clinical value of this approach. The observations of SGLT2i studies in T1DM are summarized in Table 4.

\section{Endocrinology}

SGLT2 inhibitors are also of clinical interest in diseases associated with hyponatraemia owing to their effect on free water clearance. The proof-of-concept in syndrome of inappropriate $\mathrm{ADH}$ secretion (SIADH) was evident from the
DIVE study of empagliflozin, in healthy adults with artificially induced SIADH [55]. A small placebo-controlled study (SANDx) in 84 patients with SIADH also demonstrated a significantly higher increase in plasma sodium levels with empagliflozin ( $p=0.039$ vs placebo) in addition to fluid restriction [56]. In this study, sodium overcorrection of greater than $12 \mathrm{mmol} / \mathrm{L}$ per day occurred in one patient in each group. This evidence suggests another clinical avenue for SGLT2 inhibitors in appropriate management of hyponatraemia due to SIADH.

SGLT2 inhibitors are also of clinical interest in polycystic ovarian syndrome (PCOS) due to the related pathologies of obesity and dysglycaemia. A small clinical study in patients with PCOS demonstrated weight loss and improved anthropometric parameters with empagliflozin in comparison to metformin. However, no significant differences were observed for metabolic 
Table 6 Pharmaco-ergonomic qualification tool for SGLT2 inhibitors

\begin{tabular}{|c|c|c|c|}
\hline Phenotype & Use for beneficial effect(s) & Evaluate benefit vs risk & Avoid use \\
\hline Demographic & Young/middle-aged patient & Elderly patient & $\begin{array}{l}\text { Pregnancy/lactation; } \\
\text { age }<18 \text { years }\end{array}$ \\
\hline Metabolic & $\begin{array}{l}\text { Overweight } \\
\text { Obese }\end{array}$ & Normal weight & $\begin{array}{l}\text { Lean patients; starvation; } \\
\text { frailty }\end{array}$ \\
\hline $\begin{array}{l}\text { Cardiovascular } \\
\text { and } \\
\text { haemodynamic }\end{array}$ & $\begin{array}{l}\text { Atherosclerotic CVD/HF or multiple risk } \\
\text { factors, with haemodynamic stability } \\
\text { Difficult-to-control hypertension (salt- } \\
\text { sensitive) }\end{array}$ & Risk of volume depletion & $\begin{array}{l}\text { Acute CVD event with } \\
\text { haemodynamic instability }\end{array}$ \\
\hline Renal & $\begin{array}{l}\text { Stable CKD } \\
\text { Risk factors for CKD }\end{array}$ & $\begin{array}{l}\text { History of recurrent } \\
\text { urogenital infections }\end{array}$ & $\begin{array}{l}\text { Acute renal impairment } \\
\text { eGFR }<45 \mathrm{~mL} / \mathrm{min} / \\
1.73 \mathrm{~m}^{2} \text { for glycaemic } \\
\text { control }\end{array}$ \\
\hline Hepatic & Hepatic steatosis & $\begin{array}{l}\text { Severe alcoholism (risk of } \\
\text { euDKA) }\end{array}$ & Acute medical illness \\
\hline Rheumatic disease & $\begin{array}{l}\text { Uric acid reduction (possible benefit in } \\
\text { gout) }\end{array}$ & Other comorbidities & Acute medical illness \\
\hline Comorbid & Healthy patient & $\begin{array}{l}\text { Concomitant therapy } \\
\text { (loop diuretics, } \\
\text { NSAIDS) }\end{array}$ & $\begin{array}{l}\text { Acute medical-surgical } \\
\text { illness }\end{array}$ \\
\hline
\end{tabular}

and hormonal outcomes as compared to metformin in PCOS [57].

\section{Metabolism}

SGLT2 inhibitors (in particular canagliflozin and licogliflozin) have been evaluated in a dedicated program as anti-obesity agents $[7,8]$. However, for dedicated indication of weight loss, clinically meaningful benefit of at least $5 \%$ reduction versus placebo needs to be demonstrated over 12 months [58]. The average weight loss demonstrated with selective SGLT2 inhibitors is insufficient to qualify these agents for the specific indication of weight loss. Thus, modest weight loss and corollary metabolic benefits (e.g. improved insulin sensitivity) remain pleiotropic effects of SGLT2 inhibitors, but not primary indicative benefits. Other conditions associated with increased weight, including polycystic ovarian disease or obstructive sleep apnoea, may also benefit from SGLT2 inhibitors in certain patients $[57,59,60]$. The present evidence, although limited in several aspects, does suggest clinically meaningful propositions of SGLT2 inhibitors that are worthy of further evaluation.

The non-selective SGLT1/2 dual inhibitor licogliflozin was evaluated for weight loss in patients with obesity, with or without diabetes [8]. In this 12-week placebo-controlled study, licogliflozin $150 \mathrm{mg}$ OD demonstrated weight loss of greater than $5.7 \%$ from baseline. Weight loss was significantly greater in patients with dysglycaemia (prediabetes/diabetes) compared to normoglycaemic patients. However, more than $90 \%$ of patients suffered from gastrointestinal adverse reactions, particularly diarrhoea (90.9\% of patients receiving licogliflozin versus $25 \%$ patients receiving placebo). Flatulence, abdominal pain and distension were also 
Table 7 Some key pharmacological aspects of SGLT2 inhibitors

\begin{tabular}{|c|c|c|c|}
\hline Drug & Half-life (h) & Dose $^{*}$ & $\begin{array}{l}\text { Approximate selectivity } \\
\text { (SGLT2 vs SGLT1) }\end{array}$ \\
\hline \multirow[t]{2}{*}{ Empagliflozin } & 12.4 & $10 \mathrm{mg}$ OD & 2500 fold \\
\hline & & $25 \mathrm{mg}$ OD & \\
\hline \multirow[t]{2}{*}{ Ertugliflozin } & 16.6 & $5 \mathrm{mg}$ OD & 2000 fold \\
\hline & & $15 \mathrm{mg}$ OD & \\
\hline \multirow[t]{2}{*}{ Dapagliflozin } & 12.7 & $5 \mathrm{mg}$ OD & 1200 fold \\
\hline & & $10 \mathrm{mg}$ OD & \\
\hline \multirow[t]{2}{*}{ Canagliflozin } & 10.6 & $100 \mathrm{mg}$ OD & 250 fold \\
\hline & 13.1 & $300 \mathrm{mg}$ OD & \\
\hline \multirow[t]{2}{*}{ Sotagliflozin } & 29 & $200 \mathrm{mg}$ OD & 20 fold \\
\hline & & $400 \mathrm{mg}$ OD & \\
\hline Remogliflozin & 2 & $100 \mathrm{mg} \mathrm{BD}$ & 365 fold \\
\hline \multirow[t]{2}{*}{ Ipragliflozin } & $15-16$ & $25 \mathrm{mg}$ OD & 255 fold \\
\hline & & $50 \mathrm{mg}$ OD & \\
\hline \multirow[t]{2}{*}{ Tofogliflozin } & 6.8 & $20 \mathrm{mg}$ OD & 2900 fold \\
\hline & & $40 \mathrm{mg}$ OD & \\
\hline \multirow[t]{2}{*}{ Luseogliflozin } & $9.2-13.8$ & $2.5 \mathrm{mg}$ OD & 1650 fold \\
\hline & & $5 \mathrm{mg}$ OD & \\
\hline Bexagliflozin & 5.6 & $20 \mathrm{mg} \mathrm{OD}^{\#}$ & 2435 fold \\
\hline
\end{tabular}

${ }^{*}$ Doses are described for the respective indications for each agent, as per the regulatory approvals

\# Yet to be approved for clinical use

observed more frequently in patients who received licogliflozin [8]. This safety profile is associated with non-selective inhibition of SGLT1, as was also evident with phlorizin. The development of licogliflozin as an anti-obesity agent was subsequently discontinued.

Further, while SGLT2 inhibitors have consistently demonstrated reductions in uric acid levels, the consequent rheumatic outcomes may be an area worthy of further exploration. Recently presented real-world evidence demonstrated significant 39\% lower incidence of gout in patients with T2DM receiving SGLT2i as compared to glucagon-like peptide 1 receptor agonists (GLP1-RA) [61]. A post hoc analysis of the CANVAS program also suggested significantly lower risk of gout-related events in patients receiving canagliflozin [62]. At present, confirmatory evidence of such indicative benefit remains to be elicited.

\section{PHARMACOVIGILANCE}

The safety profiles of SGTL2 inhibitors have been reviewed by various authors [63, 64]. Adverse drug reactions (ADRs) like urogenital infections, euDKA, volume-depletion-related ADRs and acute kidney injury are class effects for SGLT2 inhibitors. According to a recent review by Shi et al. [63], relative risks of ADRs 
from placebo-controlled RCTs of various SGLT2 inhibitors are as follows:

- Drug-related ADRs: 1.34 (95\% CI 1.26, 1.43)

- Urinary tract infections: 1.04 (95\% CI 0.97, 1.11)

- Genital tract infections: 3.71 (95\% CI 3.19, 4.32)

- Volume-depletion related ADRs: 1.26 (95\% CI 1.08, 1.46)

In another systematic review of RCTs of SGLT2 inhibitors, performed by Donnan et al. [64], the relative risk of acute kidney injury (AKI) was 0.59 (95\% CI $0.39,0.89)$, and that of euDKA was 0.66 (95\% CI 0.30-1.45).

Of particular note, serious skin and subcutaneous tissue infections have been implicated more closely with ipragliflozin, based on its greater affinity for melanin [65]. Canagliflozin and ertugliflozin have demonstrated increased risk of lower limb amputations, whereas bone fracture risk has been specifically observed with canagliflozin in the clinically indicated range of eGFR [66, 67]. Several plausible mechanisms for these adverse reactions have been proposed, and are reviewed elsewhere $[68,69]$. The CREDENCE study was designed with specific measures to minimize the risk of lower limb amputations; this study did not demonstrate significantly increased risk of lower limb amputations with canagliflozin [5]. The safety outcomes observed in SGLT2 inhibitor CVOTs and CREDENCE are summarized in Table 5.

\section{PHARMACO-ERGONOMICS}

We had earlier published a pharmaco-ergonomic qualification tool for appropriate clinical use of SGLT2 inhibitors [70]. An updated version of the qualification tool, based on contemporary evidence, is presented in Table 6.

Various available SGLT2 inhibitors, and their basic pharmacological characteristics, are summarized in Table 7 [66, 67, 71-82].

\section{CONCLUSION}

SGLT2 inhibitors have assumed increasing clinical relevance in several aspects beyond glycaemic control in T2DM. It is, therefore, imperative for physicians to stay updated and mindful of the facts to ensure continual practice of good evidence-based medicine.

\section{ACKNOWLEDGEMENTS}

Funding. No funding or sponsorship was received for this study or publication of this article.

Authorship. All named authors meet the International Committee of Medical Journal Editors (ICMJE) criteria for authorship for this article, take responsibility for the integrity of the work as a whole, and have given their approval for this version to be published.

Disclosures. Kimi Shetty, Vetrivel Babu Nagarajan and Jignesh Ved are employed by Boehringer Ingelheim. Their contribution to this manuscript reflects their own personal views on the topic; it does not suggest the views of Boehringer Ingelheim, directly or indirectly. Sanjay Kalra has been a speaker for AstraZeneca, Boehringer Ingelheim and Janssen, and has received speaker fees towards the same. Sanjay Kalra is a member of the journal's Editorial Board.

Compliance with Ethics Guidelines. This article is based on previously conducted studies and does not contain any studies with human participants or animals performed by any of the authors.

Open Access. This article is licensed under a Creative Commons Attribution-NonCommercial 4.0 International License, which permits any non-commercial use, sharing, adaptation, distribution and reproduction in any medium or format, as long as you give appropriate credit to the original author(s) and the source, provide a link to the Creative Commons licence, and indicate if changes were made. The images or other third party material in this article are included in the article's Creative Commons licence, unless indicated otherwise in a credit 
line to the material. If material is not included in the article's Creative Commons licence and your intended use is not permitted by statutory regulation or exceeds the permitted use, you will need to obtain permission directly from the copyright holder. To view a copy of this licence, visit http://creativecommons.org/licenses/by$\mathrm{nc} / 4.0 /$.

\section{REFERENCES}

1. Zinman B, Wanner C, Lachin JM, et al. Empagliflozin, cardiovascular outcomes, and mortality in type 2 diabetes. N Engl J Med. 2015;373(22): 2117-28.

2. USFDA. Drug Safety Communications. FDA warns that SGLT2 inhibitors for diabetes may result in a serious condition of too much acid in the blood. 2015 . https://www.fda.gov/media/92185/ download. Accessed 29 Nov 2019.

3. USFDA. Drug Safety Communications. FDA confirms increased risk of leg and foot amputations with the diabetes medicine canagliflozin (Invokana, Invokamet, Invokamet XR). 2017. https://www.fda. gov/media/104870/download. Accessed 29 Nov 2019.

4. Ved J, Paul K, Kalra S. Vasculo-metabolic axis in type 2 diabetes mellitus-abductive reasoning from sodium glucose cotransporter-2 inhibitor evidence. US Endocrinol. 2019;15(1):27-31.

5. Perkovic V, Jardine MJ, Neal B, et al. Canagliflozin and renal outcomes in type 2 diabetes and nephropathy. N Engl J Med. 2019;380(24): 2295-306.

6. McMurray JJ, Solomon SD, Inzucchi SE, et al. Dapagliflozin in patients with heart failure and reduced ejection fraction. $\mathrm{N}$ Engl $\mathrm{J}$ Med. 2019;381(21):1995-2008.

7. Hollander P, Bays HE, Rosenstock J, et al. Coadministration of canagliflozin and phentermine for weight management in overweight and obese individuals without diabetes: a randomized clinical trial. Diabetes Care. 2017;40(5):632-9.

8. He YL, Haynes W, Meyers CD, et al. The effects of licogliflozin, a dual SGLT1/2 inhibitor, on body weight in obese patients with or without diabetes. Diabetes Obes Metab. 2019;21(6):1311-21.
9. Kalra S. Sodium glucose co-transporter-2 (SGLT2) inhibitors: a review of their basic and clinical pharmacology. Diabetes Ther. 2014;5(2):355-66.

10. Fitchett DH. Empagliflozin and cardio-renal outcomes in patients with type 2 diabetes and cardiovascular disease-implications for clinical practice. Eur Endocrinol. 2018;14(2):40.

11. Fitchett D, Inzucchi SE, Cannon CP, et al. Empagliflozin reduced mortality and hospitalization for heart failure across the spectrum of cardiovascular risk in the EMPA-REG OUTCOME trial. Circulation. 2019;139(11):1384-95.

12. Inzucchi SE, Kosiborod $\mathrm{M}$, Fitchett $\mathrm{D}$, et al. Improvement in cardiovascular outcomes with empagliflozin is independent of glycemic control. Circulation. 2018;138(17):1904-7.

13. Huttner S, Zinman B, Fitchett D, et al. EMPA-REG OUTCOME: empagliflozin (EMPA) reduced the risk of cardiovascular (CV) outcomes and mortality irrespective of metformin (MET) use at baseline. Abstract 919. Presented at 53rd annual meeting of the European Association for the Study of Diabetes. 2017 Sep 11-15. Lisbon, Portugal.

14. Neal B, Perkovic V, Mahaffey KW, et al. Canagliflozin and cardiovascular and renal events in type 2 diabetes. N Engl J Med. 2017;377(7):644-57.

15. Wiviott SD, Raz I, Bonaca MP, et al. Dapagliflozin and cardiovascular outcomes in type 2 diabetes. N Engl J Med. 2019;380(4):347-57.

16. Zelniker TA, Wiviott SD, Raz I, Im K, et al. SGLT2 inhibitors for primary and secondary prevention of cardiovascular and renal outcomes in type 2 diabetes: a systematic review and meta-analysis of cardiovascular outcome trials. Lancet. 2019;393(10166):31-9.

17. Uthman L, Baartscheer A, Schumacher CA, et al. Direct cardiac actions of sodium glucose cotransporter 2 inhibitors target pathogenic mechanisms underlying heart failure in diabetic patients. Front Physiol. 2018;9:1575.

18. Lan NS, Fegan PG, Yeap BB, Dwivedi G. The effects of sodium-glucose cotransporter 2 inhibitors on left ventricular function: current evidence and future directions. ESC Heart Fail. 2019;6(5):927-35.

19. Verma S. Potential mechanisms of sodium-glucose co-transporter 2 inhibitor-related cardiovascular benefits. Am J Cardiol. 2019;15(124):S36-44.

20. Verma S, Mazer CD, Yan AT, et al. Effect of empagliflozin on left ventricular mass in patients with type 2 diabetes mellitus and coronary artery disease: 
the EMPA-HEART CardioLink-6 randomized clinical trial. Circulation. 2019;140(21):1693-702.

21. Garg V, Verma S, Connelly KA, et al. Does empagliflozin modulate the autonomic system among patients with type 2 diabetes and coronary artery disease? Insights from the Holter sub-study of the EMPA-Heart CardioLink-6 randomised trial. Presented at ESC Congress 2019 together with World Congress of Cardiology. 2019 Aug 31-Sep 4. Paris, France.

22. Bami K, Gandhi S, Leong-Poi H, et al. Effects of empagliflozin on cardiac function in patients with type 2 diabetes mellitus: echocardiographic substudy of the EMPA-HEART cardiolink-6 trial. Presented at ESC Congress 2019 together with World Congress of Cardiology. 2019 Aug 31-Sep 4. Paris, France.

23. Al-Jobori H, Daniele G, Cersosimo E, et al. Empagliflozin and kinetics of renal glucose transport in healthy individuals and individuals with type 2 diabetes. Diabetes. 2017;66(7):1999-2006.

24. Lam CS, Chandramouli C, Ahooja V, Verma S. SGLT-2 inhibitors in heart failure: current management, unmet needs, and therapeutic prospects. J Am Heart Assoc. 2019;8(20):e013389.

25. Savarese G, Sattar N, Januzzi J, et al. Empagliflozin is associated with a lower risk of post-acute heart failure rehospitalization and mortality: insights from the EMPA-REG OUTCOME trial. Circulation. 2019;139(11):1458-60.

26. Anonymous. A study to test the effect of empagliflozin in patients who are in hospital for acute heart failure. ClinicalTrals.gov, US NLM. https://www. clinicaltrials.gov/ct2/show/NCT04157751. Accessed Nov 29, 2019.

27. Rajput R, Ved J. Reverse causality in Empa-Reg outcome: the proverbial elephant? Diabetes Res Clin Pract. 2017;100(127):288-9.

28. Furtado RH, Bonaca MP, Raz I, et al. Dapagliflozin and cardiovascular outcomes in patients with type 2 diabetes mellitus and previous myocardial infarction: subanalysis from the DECLARE-TIMI 58 trial. Circulation. 2019;139(22):2516-27.

29. Hallow KM, Helmlinger G, Greasley PJ, McMurray JJ, Boulton DW. Why do SGLT2 inhibitors reduce heart failure hospitalization? A differential volume regulation hypothesis. Diabetes Obes Metab. 2018;20(3):479-87.

30. Striepe K, Jumar A, Ott C, et al. Effects of the selective sodium-glucose cotransporter 2 inhibitor empagliflozin on vascular function and central hemodynamics in patients with type 2 diabetes mellitus. Circulation. 2017;136(12):1167-9.

31. Kario K, Okada K, Kato M, et al. Twenty-four-hour blood pressure-lowering effect of a sodium-glucose cotransporter 2 inhibitor in patients with diabetes and uncontrolled nocturnal hypertension: results from the randomized, placebo-controlled SACRA study. Circulation. 2019;139(18):2089-97.

32. Ferreira JP, Fitchett D, Ofstad AP, et al. Empagliflozin in resistant hypertension: findings from the EMPA-REG OUTCOME ${ }^{\circledR}$ trial. Presented at AHA Conference. 2019 Nov 16-18. Philadelphia, USA.

33. Obeid A, Pucci M, Martin U, Hanif W. Sodium glucose co-transporter 2 inhibitors in patients with resistant hypertension: a case study. JRSM Open. 2016;7(9):2054270416649285.

34. Silva dos Santos D, Polidoro JZ, Borges-Júnior FA, Girardi AC. Cardioprotection conferred by sodiumglucose cotransporter 2 inhibitors: a renal proximal tubule perspective. Am J Physiol Cell Physiol. 2020;318:C328-36.

35. Triplitt CL. Understanding the kidneys' role in blood glucose regulation. Am J Manag Care. 2012;18(1 Suppl):S11-6.

36. Cherney DZI, Bakris GL. Novel therapies for diabetic kidney disease. Kidney Int Suppl. 2018;8: 18-25.

37. Sarafidis P, Ferro CJ, Morales E, et al. SGLT-2 inhibitors and GLP-1 receptor agonists for nephroprotection and cardioprotection in patients with diabetes mellitus and chronic kidney disease. A consensus statement by the EURECA-m and the DIABESITY working groups of the ERA-EDTA. Nephrol Dial Transplant. 2019;34:208-30.

38. Herrington WG, Preiss D, Haynes R, et al. The potential for improving cardio-renal outcomes by sodium-glucose co-transporter-2 inhibition in people with chronic kidney disease: a rationale for the EMPA-KIDNEY study. Clin Kidney J. 2018;11: 749-61.

39. Anonymous. A study to evaluate the effect of dapagliflozin on renal outcomes and cardiovascular mortality in partients with chronic kidney disease (Dapa-CKD). ClinicalTrials.gov, US NLM. https:// clinicaltrials.gov/ct2/show/NCT03036150. Accessed 30 Nov 2019

40. Sano M, Goto S. Possible mechanism of hematocrit elevation by sodium glucose cotransporter 2 inhibitors and associated beneficial renal and cardiovascular effects. Circulation. 2019;139:1985-7. 
41. Scheen AJ. Beneficial effects of SGLT2 inhibitors on fatty liver in type 2 diabetes: a common comorbidity associated with severe complications. Diabetes Metab. 2019;45(3):213-23.

42. European Medicines Agency. Reflection paper on regulatory requirements for the development of medicinal products for chronic non6 infectious liver diseases (PBC, PSC, NASH). 2018. https://www. ema.europa.eu/en/documents/scientific-guideline/ reflection-paper-regulatory-requirements-development-medicinal-products-chronic-non-infectiousliver_en.pdf. Accessed 1 Dec 2019.

43. Kuchay MS, Krishan S, Mishra SK, et al. Effect of empagliflozin on liver fat in patients with type 2 diabetes and nonalcoholic fatty liver disease: a randomized controlled trial (E-LIFT trial). Diabetes Care. 2018;41(8):1801-8.

44. Akuta N, Watanabe C, Kawamura Y, et al. Effects of a sodium-glucose cotransporter 2 inhibitor in nonalcoholic fatty liver disease complicated by diabetes mellitus: preliminary prospective study based on serial liver biopsies. Hepatol Commun. 2017;1(1):46-52.

45. Akuta N, Kawamura Y, Watanabe C, et al. Impact of sodium glucose cotransporter 2 inhibitor on histological features and glucose metabolism of non-alcoholic fatty liver disease complicated by diabetes mellitus. Hepatol Res. 2019;49(5):531-9.

46. Riddle M, Cefalu W. SGLT inhibitors for type 1 diabetes: an obvious choice or too good to be true? Diabetes Care. 2018;41(12):2444-7.

47. McCrimmon RJ, Henry RR. SGLT inhibitor adjunct therapy in type 1 diabetes. Diabetologia. 2018;61(10):2126-33. https://doi.org/10.1007/ s00125-018-4671-6.

48. Henry R, Thakkar P, Tong C, Polidori D, Alba M. Efficacy and safety of canagliflozin, a sodium-glucose cotransporter 2 inhibitor, as add-on to insulin in patients with type 1 diabetes. Diabetes Care. 2015;38(12):2258-65.

49. Buse J, Garg S, Rosenstock J, et al. Sotagliflozin in combination with optimized insulin therapy in adults with type 1 diabetes: the North American inTandem1 study. Diabetes Care. 2018;41(9): 1970-80.

50. Danne T, Cariou B, Banks $\mathrm{P}$, et al. HbA1c and hypoglycemia reductions at 24 and 52 weeks with sotagliflozin in combination with insulin in adults with type 1 diabetes: the European inTandem2 study. Diabetes Care. 2018;41(9):1981-90.
51. Garg S, Henry R, Banks P, et al. Effects of sotagliflozin added to insulin in patients with type 1 diabetes. N Engl J Med. 2017;377(24):2337-48.

52. Rosenstock J, Marquard J, Laffel L, et al. Empagliflozin as adjunctive to insulin therapy in type 1 diabetes: the EASE trials. Diabetes Care. 2018;41(12):2560-9.

53. Dandona P, Mathieu C, Phillip M, et al. Efficacy and safety of dapagliflozin in patients with inadequately controlled type 1 diabetes (DEPICT-1): 24 week results from a multicentre, double-blind, phase 3 , randomised controlled trial. Lancet Diabetes Endocrinol. 2017;5(11):864-76.

54. Mathieu C, Dandona P, Gillard P, et al. Efficacy and safety of dapagliflozin in patients with inadequately controlled type 1 diabetes (the DEPICT-2 study): 24-week results from a randomized controlled trial. Diabetes Care. 2018;41(9):1938-46.

55. Refardt J, Winzeler B, Meienberg F, Vogt DR, ChristCrain M. Empagliflozin increases short-term urinary volume output in artificially induced syndrome of inappropriate antidiuresis. Int J Endocrinol. 2017. https://doi.org/10.1155/2017/ 7815690 .

56. Refardt J, Imber C, Sailer CO, et al. Empagliflozin increases sodium-levels in patients with the syndrome of inappropriate antidiuretic hormone secretion-a randomized, double-blind, placebocontrolled trial. Presented at 21st European Congress of Endocrinology. 2019 May 18-21. Lyon, France.

57. Javed Z, Papageorgiou M, Deshmukh H, et al. Effects of empagliflozin on metabolic parameters in polycystic ovary syndrome: a randomized controlled study. Clin Endocrinol. 2019;90(6):805-13.

58. European Medicines Agency. Guideline on clinical evaluation of medicinal products used in weight management. 2016. https://www.ema.europa.eu/ en/documents/scientific-guideline/guideline-clinicalevaluation-medicinal-products-used-weight-management-revision-1_en.pdf. Accessed 1 Dec 2019.

59. Tang Y, Sun Q, Bai XY, Zhou YF, Zhou QL, Zhang M. Effect of dapagliflozin on obstructive sleep apnea in patients with type 2 diabetes: a preliminary study. Nutr Diabetes. 2019;9(1):1-6.

60. Sawada K, Karashima S, Kometani M, et al. Effect of sodium glucose cotransporter 2 inhibitors on obstructive sleep apnea in patients with type 2 diabetes. Endocr J. 2018;65(4):461-7.

61. Fralick M, Chen S, Patorno E, Kim SC. Assessing the risk of gout with sodium glucose co-transporter-2 inhibitors: a population-based cohort study. 
Presented at 2019 ACR/ARP Annual Meeting. 2019 Nov 8-13. Atlanta, GA .

62. Li J, Badve SV, Zhou Z, et al. The effects of canagliflozin on gout in type 2 diabetes: a post hoc analysis of the CANVAS program. Lancet Rheumatol. $2019 ; 1(4): \mathrm{e} 220-8$.

63. Shi FH, Li H, Shen L, et al. Appraisal of non-cardiovascular safety for sodium-glucose co-transporter 2 inhibitors: a systematic review and metaanalysis of placebo-controlled randomized clinical trials. Front Pharmacol. 2019;10:1066.

64. Donnan JR, Grandy CA, Chibrikov E, et al. Comparative safety of the sodium glucose co-transporter 2 (SGLT2) inhibitors: a systematic review and metaanalysis. BMJ Open. 2019;9(1):e022577.

65. Sakaeda T, Kobuchi S, Yoshioka R, et al. Susceptibility to serious skin and subcutaneous tissue disorders and skin tissue distribution of sodiumdependent glucose co-transporter type 2 (SGLT2) inhibitors. Int J Med Sci. 2018;15(9):937-43.

66. USFDA. Invokana prescribing information. Belgium: Janssen Pharmaceuticals; 2019.

67. USFDA. Steglatro prescribing information. Kenilworth: Merck Sharp \& Dohme; 2019.

68. Katsiki N, Dimitriadis G, Hahalis G, et al. Sodiumglucose co-transporter-2 inhibitors (SGLT2i) use and risk of amputation: an expert panel overview of the evidence. Metabolism. 2019;96:92-100.

69. Erythropoulou-Kaltsidou A, Polychronopoulos G, Tziomalos K. Sodium-glucose co-transporter 2 inhibitors and fracture risk. Diabetes Ther. 2019;16: $1-8$.

70. Kalra S, Unnikrishnan AG, Baruah M, Kawatra P, Ved J. Sodium-glucose cotransporter 2 inhibitor use: a pharmaco-ergonomic qualification tool. Indian J Endocrinol Metab. 2017;21(5):762-4.

71. USFDA. Jardiance prescribing information. Ingelheim am rhein: Boehringer Ingelheim; 2018.

72. European Medicines Agency. CHMP Assessment Report-empagliflozin. 2014.
73. Grempler R, Thomas L, Eckhardt M, et al. Empagliflozin, a novel selective sodium glucose cotransporter-2 (SGLT-2) inhibitor: characterisation and comparison with other SGLT-2 inhibitors. Diabetes Obes Metab. 2012;14(1):83-90.

74. European Medicines Agency. CHMP Assessment Report-ertugliflozin. 2018.

75. USFDA. Farxiga prescribing information. Cambridge: AstraZeneca; 2014.

76. Ohkura T. Ipragliflozin: a novel sodium-glucose cotransporter 2 inhibitor developed in Japan. World J Diabetes. 2015;6(1):136.

77. Samukawa Y, Mutoh M, Chen S, Mizui N. Mechanism-based pharmacokinetic-pharmacodynamic modeling of luseogliflozin, a sodium glucose cotransporter 2 inhibitor, in Japanese patients with type 2 diabetes mellitus. Biol Pharm Bull. 2017;40(8):1207-18.

78. O'Connor-Semmes R, Walker S, Kapur A, et al. Pharmacokinetics and pharmacodynamics of the SGLT2 inhibitor remogliflozin etabonate in subjects with mild and moderate renal impairment. Drug Metab Dispos. 2015;43(7):1077-83.

79. Fujimori Y, Katsuno K, Nakashima I, IshikawaTakemura Y, Fujikura H, Isaji M. Remogliflozin etabonate, in a novel category of selective lowaffinity sodium glucose cotransporter (SGLT2) inhibitors, exhibits antidiabetic efficacy in rodent models. J Pharmacol Exp Ther. 2008;327(1):268-76.

80. Poole RM, Prossler JE. Tofogliflozin: first global approval. Drugs. 2014;74(8):939-44.

81. Markham A, Keam SJ. Sotagliflozin: first global approval. Drugs. 2019;6:1-7.

82. Halvorsen YD, Walford G, Thurber T, Russell $H$, Massaro M, Freeman MW. A twelve-week, randomized, double-blind, placebo-controlled, fourarm dose-finding phase 2 study evaluating bexagliflozin as a monotherapy for adults with type 2 diabetes. Diabetes Obes Metab. 2019. https://doi. org/10.1111/dom.13928. 